\title{
Medicinal Properties Screening of Mallotus paniculatus Extract
}

\author{
Bahaman NA $A^{a}$, Ahmad Raus $R^{a}$, Ahmad Nor Ya, Mamun AA $A^{a}$, Adzahar NS ${ }^{b}$, Basri DF \\ ${ }^{a}$ Faculty of Engineering, International Islamic University Malaysia \\ ${ }^{b}$ Faculty of Industrial Sciences \& Technology, Universiti Malaysia Pahang \\ ${ }^{c}$ Faculty of Health Sciences, Universiti Kebangsaan Malaysia
}

\begin{abstract}
Introduction: Traditionally, Mallotus paniculatus (Balik Angin) plant is used in the treatment of various diseases in rural areas such as remedy after childbirth, wound healing and fever. In this present study, four medicinal properties of the plant were investigated which included antibacterial, antifungal, anticancer and antioxidant activities. Materials and Methods: Potential medicinal compounds were extracted from the plant leaves by sonication with 3 different solvents namely ethanol, ethyl acetate and hexane respectively. The antibacterial and antifungal properties were determined using disc diffusion agar and broth dilution assay, the antioxidant activity by DPPH scavenging assay and the anticancer effect by MTT assay. Results: From the screening of the medicinal properties, M. paniculatus leave extracts were shown to possess antibacterial, antioxidant and anticancer properties but not antifungal properties. Ethanolic and ethyl acetate extracts of the leave were active against gram positive bacteria (Staphylococcus aureus and Bacillus subtilis) but not gram negative bacteria (Pseudomonas aeruginosa and Escherichia coli). The antioxidant activity of the ethanolic crude extract was high; with $\mathrm{IC}_{50}$ of $30 \mu \mathrm{g} / \mathrm{ml}$ comparable with the positive controls; ascorbic acid and butylated hydroxytoluene (BHT). Both ethanolic and ethyl acetate extracts were cytotoxic against breast cancer (MCF7), colon cancer (HT-29), cervix cancer (Hela) cell lines. Conclusion: M. paniculatus leave extract has many potential medicinal values for further studies.
\end{abstract}

KEYWORDS: Mallotus paniculatus, antibacterial, anticancer, antioxidant, sonication

\section{INTRODUCTION}

Natural products are very useful ${ }^{1}$ and economically essential $^{2}$ as it is relatively cost-effective ${ }^{3}$ than modern drugs $^{3}$ and it has been used in traditional medicine. ${ }^{4}$ Undoubtedly, scientific investigation on the traditional medicinal plants has greatly helped the natural products to be marketable commercially and has taken a secondary role in drug discovery and drug development. ${ }^{5}$ The increasing demand for natural products in maintaining health ${ }^{6}$ and treating diseases $^{7}$ encourages many researchers globally to investigate traditional medicinal plants extensively. ${ }^{8}$

Corresponding author

Assoc. Prof. Dr. Raha Ahmad Raus

Faculty of Engineering,

International Islamic University Malaysia

Tel No : 03-61964588

Email : rahaar@iium.edu.my
In Malaysia, there are many traditional medicinal plants, including petai (Parkia speciosa), pegaga (Centella asiatica), kunyit (Curcuma domestica), asam gelugor (Garcinia atroviridis) and papaya fruit (Carica papaya). ${ }^{9}$ Scientific studies showed that $P$. speciosa and $C$. asiatica possess anti-diabetics, anti-oxidant as well as anti-hypertensive activities ${ }^{10}$ while $C$. domestica demonstrated anti-inflammatory, anti-tumour, cardio-protective and neuro-protective properties. ${ }^{9} \quad G$. atroviridis was found to possess antibacterial, anti-nematodes, anti-tumour activities, and $C$. papaya has antioxidant property. ${ }^{11}$

Another traditional medicinal plant in Malaysia that is used to treat diseases is Mallotus paniculatus. ${ }^{12}$ In Malaysia, the local name of this tree is 'Balik angin'. Often it is utilized as a remedy after childbirth, for wound healing and fever treatment. It belongs to Euphorbiaceae family which is a major group of angiosperm (flowering plant) commonly found in southern Asia including Malaysia and north-eastern 


\section{INTRODUCTION}

Natural products are very useful ${ }^{1}$ and economically essential $^{2}$ as it is relatively cost-effective ${ }^{3}$ than modern drugs $^{3}$ and it has been used in traditional medicine. ${ }^{4}$ Undoubtedly, scientific investigation on the traditional medicinal plants has greatly helped the natural products to be marketable commercially and has taken a secondary role in drug discovery and drug development. ${ }^{5}$ The increasing demand for natural products in maintaining health ${ }^{6}$ and treating diseases ${ }^{7}$ encourages many researchers globally to investigate traditional medicinal plants extensively. ${ }^{8}$

In Malaysia, there are many traditional medicinal plants, including petai (Parkia speciosa), pegaga (Centella asiatica), kunyit (Curcuma domestica), asam gelugor (Garcinia atroviridis) and papaya fruit (Carica papaya). ${ }^{9}$ Scientific studies showed that $P$. speciosa and $C$. asiatica possess anti-diabetics, anti-oxidant as well as anti-hypertensive activities ${ }^{10}$

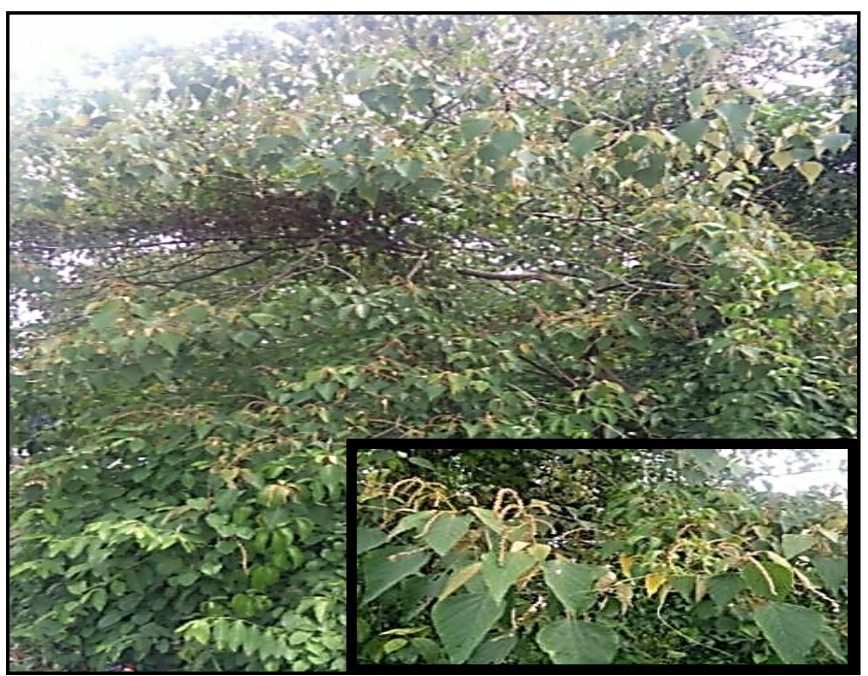

Figure 1: 'Balik angin' trees were found at Jalan Kepong, Selayang

\section{MATERIALS AND METHODS}

Collection of plant material

The plant material used in this experiment was collected from an area in Selayang, Malaysia. The species was identified and authenticated by a certified officer from the National Herbarium of Forest Research Institution Malaysia (FRIM) (PID 321017-20). The leaves were dried, grounded to become powder and stored for extraction. Only plant leaves were used in the present study as most traditional medicinal practices used this part of the plant in the treatment modality.
Preparation of the Extracts

Plant crude extracts were prepared by extracting the powdered leaves with ethanol, hexane and ethyl acetate individually in an ultrasonic bath (JAC Ultrasonic 4020, Korea) in a ratio of $1: 10(\mathrm{w} / \mathrm{v})(\mathrm{g} /$ $\mathrm{ml}$ ) at a temperature of $40^{\circ} \mathrm{C}$ for $30 \mathrm{~min}$ with amplitude $24 \mathrm{kHz}$. The decoction was filtered using the Whatman paper and the resulting filtrate was dried at $50^{\circ} \mathrm{C}$ for $4-7$ hours. Various solvents were used in this study to obtain compounds of different polarities.

\section{Bacterial and Fungal Cultures}

The bacteria and fungi used in the present study were Escherichia coli (ATCC 25922), Pseudomonas aeruginosa (ATCC 15442) as gram negative species and Staphylococcus aureus (ATCC 25923), Bacillus subtilis (ATCC 23857) as gram positive species; and fungi: Candida albicans (ATCC 90028), Candida glabrata (ATCC 24433), Aspergillus niger, respectively.

\section{Mammalian Cell culture}

The cell lines involved in this study were breast cancer (MCF-7, ATCC No: HTB-22), colon cancer (HT29, ATCC No: HTB-38) and cervical cancer (Hela, ATCC No: CCL-2), while normal cell (Vero, ATCC No: CCL-81) was used as the negative control. These cell lines were cultured in Dulbecco's Modified Eagle's Medium (DMEM) supplemented with $10 \%$ foetal bovine serum (FBS) at $37^{\circ} \mathrm{C}$ in an incubator supplied with $5 \% \mathrm{CO}_{2}$ until confluent. The confluent cells were trypsinized and cell count was conducted under microscope using a haemocytometer for cytotoxic assay.

\section{Agar Disc Diffusion Assay}

Antibacterial and antifungal activities of the plant leave extracts were tested by agar disc diffusion method with few modifications. ${ }^{17}$ To conduct the assay, the bacteria and fungi were first plated on Luria Bertani (LB) agar and potato dextrose agar, separately and incubated at $37^{\circ} \mathrm{C}$ for $18-24$ hours and 48 hours, respectively. These bacterial and fungal cultures were then transferred into freshly prepared LB and potato dextrose broth respectively and adjusted to 0.5 McFarland turbidity standards $(1.5 \mathrm{X}$ $10^{8}$ cells $/ \mathrm{ml}$ at a wavelength of $600 \mathrm{~nm}$ and $540 \mathrm{~nm}$, 
respectively) by diluting them with sterile distilled water. The adjusted inoculums of $100 \mu \mathrm{l}$ were then plated on the Mueller Hinton agar plates before 6 $\mathrm{mm}$ round-shaped filter paper impregnated with leaves extracts ( $5 \mathrm{mg}$ per disc) were placed on the plates. Antibiotic, streptomycin $(100 \mu \mathrm{g})$ was used as the positive control while disc impregnated with $10 \%$ dimethyl sulfoxide (DMSO) served as the negative control. For this assay, $0.5 \mathrm{~g} / \mathrm{ml}$ extracts were prepared by dissolving the dried filtrate in $10 \%$ DMSO. The test was determined by the size of the zone of inhibition which indicated the sensitivity of the microorganism to the extract.

\section{Broth Dilution Assay}

For broth dilution assay, bacterial suspension culture was prepared by adjusting it to 0.5 McFarland turbidity standards at $600 \mathrm{~nm}$ wavelength. Then, $100 \mu \mathrm{L}$ of the culture was placed into a 96-well microplate. This was followed by adding $5 \mathrm{mg} / \mathrm{mL}$ of plant extract into the microplate. A serial dilution of the extracts was made and the plate was incubated overnight. The optical density (OD) of overnight culture was measured to determine half maximal inhibitory concentration $\left(\mathrm{IC}_{50}\right)$ of the plant extracts. All determinations were performed in triplicate readings.

\section{Antioxidant activity by 2,2'-Diphenyl-1- picrylhydrazyl radical (DPPH) scavenging assay}

For this assay, the sample solution at $1 \mathrm{mg} / \mathrm{ml}$ was prepared by mixing the crude extracts with ethanol and was diluted to a dilution series. ${ }^{18}$ This was followed by mixing them $(100 \mu \mathrm{L})$ with $3.9 \mathrm{~mL}$ of methanolic DPPH in a $15 \mathrm{~mL}$ test tube, individually. The mixtures were then allowed to stand for 30 minutes at room temperature in the dark. At the same time, a control containing $100 \mu \mathrm{L}$ of ethanol and methanolic DPPH was prepared and was also left in the dark. After that, the absorbance (OD) of the control and the sample were measured at $517 \mathrm{~nm}$ by using UV spectrophotometer. All determinations were performed in triplicate readings. The DPPH radical scavenging activity of the tested samples was calculated according to equation shown below. ${ }^{19} \mathrm{~A}$ radical scavenging activity versus concentration of the sample was plotted and the concentration of sample required for $50 \%$ activity were determined and represented as $\mathrm{IC}_{50}$ value.

DPPH radical scavenging activity $(\%)=\left[\frac{[0 D \text { control }-0 D \text { sample }]}{0 \mathrm{D} \text { control }}\right] \times 100 \%$

\section{Cytotoxic activity by MTT assay}

MTT (3-(4,5-dimethylthiazol-2-yl)-2, 5-diphenyltetrazolium bromide) assay is a colorimetric assay for assessing cell metabolic activity. The assay was carried out by seeding a known number of cells $(5 \times$ $10^{3} \mathrm{cell} /$ well in $100 \mu \mathrm{l}$ of DMEM supplemented with serum) into a 96-well plate and incubated for 24 hours before adding plant extract with different dilutions. MTT at $0.5 \mathrm{mg} / \mathrm{ml}$ were added into the wells after 24 hours treatment and DMSO was later transferred to each well to solubilize the MTT formazan formed. The control $\left(5 \times 10^{3} \mathrm{cell} /\right.$ well in $100 \mu \mathrm{l}$ medium with serum) was carried out at the same time without plant extract treatment. Absorbance at $540 \mathrm{~nm}$ of each well was recorded using microplate reader. The results were analysed in triplicate and the cytotoxic effect of the extract was evaluated based on the percentage of cell viability using the following equation $2 ;^{20}$

$$
\text { Cell Viability }(\%)=\frac{\text { OD sample }}{\text { OD of control }} \times 100 \%
$$

\section{RESULT AND DISCUSSION}

\section{Antibacterial and antifungal activities}

\section{i. Disc diffusion assay}

Table I shows that ethanolic and ethyl acetate extracts possess antibacterial activity against $S$. aureus and $B$. subtilis with inhibition zone, $14 \mathrm{~mm}$ and $11 \mathrm{~mm}$, respectively. However, none of the plant extracts showed inhibition against $E$. coli and $P$. aeruginosa growth. These results indicated that gram positive bacteria are more susceptible towards the plant extracts compared to the gram negative bacteria. The different effect of these extracts may be due to cell wall structure of gram negative and gram positive bacteria. Although the bacterial cell wall of gram positive compose of a thicker peptidoglycans layer compared to the gram negative bacteria, the latter has an outer membrane which function as an extra layer of protection to the organism. ${ }^{21}$ Hence, it may cause the gram negative bacteria to be less susceptible towards the plant extracts.

The results also demonstrated that the ethanolic extract possessed a better antibacterial activity compared to the other extracts. The hexane extract did not show any inhibition zone against all the bacteria. This may be due to the different chemical 
constituents isolated in the extracts depending on the polarity of each solvent used as extractant. ${ }^{22}$ Previous study found that M. paniculatus methanol extract consists of flavonoids and pentacyclic triterpenoids. ${ }^{23}$ Flavonoids are hydroxylated phenolic substances in the form of $\mathrm{C} 6-\mathrm{C} 3$ unit linked to an aromatic ring. They are known to be effective antimicrobial substances against a wide array of microorganisms. This activity could be due to their ability to form complex with extracellular and soluble proteins through nonspecific forces such as hydrogen bonding, hydrophobic effects and covalent bonding. They are also able to bind with bacterial cell walls, microbial adhesins, enzymes, and cell envelope transport proteins. This may result in the loss of vital metabolites from the cells and becomes responsible for the death of the cells. ${ }^{24}$

Table I : Inhibition zone of Mallotus paniculatus leave extracts with different solvents towards various bacteria

\begin{tabular}{lllll}
\hline & \multicolumn{3}{l}{ Inhibition zone $(\mathrm{mm})$} \\
\cline { 2 - 5 } Bacteria & $\begin{array}{l}\text { Strepto- } \\
\text { mycin }\end{array}$ & Ethanol $\begin{array}{l}\text { Ethyl } \\
\text { acetate }\end{array}$ & Hexane \\
\cline { 2 - 5 } & 22 & $14 \pm$ & $11 \pm$ & - \\
\hline $\begin{array}{l}\text { Staphylococ- } \\
\text { cus aureus }\end{array}$ & 22 & 0.5 & 0.5 & \\
$\begin{array}{l}\text { Bacillus } \\
\text { subtilis }\end{array}$ & 20 & $14 \pm$ & $11 \pm$ & - \\
$\begin{array}{l}\text { Escherichia } \\
\text { coli }\end{array}$ & 32 & 0.6 & 0.9 & \\
$\begin{array}{l}\text { Pseudomonas } \\
\text { aeruginosa }\end{array}$ & 25 & - & - & - \\
\hline
\end{tabular}

Triterpenoids that were found in $M$. paniculatus extract were sterols; friedelin, epifriedelinol, 29-nor-21aH-hopane-3, 22-dione, and steroids; B-itosterol, stigmasterol. ${ }^{14}$ Pentacyclic triterpenoids in Limnophila indica Linn have been shown to be toxic toward microorganism. ${ }^{25}$ However, no study has been conducted yet on triterpenoids in $M$. paniculatus for the same bioactivity.

Regarding the antifungal activity however all the crude extracts did not show any inhibition zone against these fungi species; Candida albicans, Candida glabrata, and Aspergillus niger. This could be due to resistance of the fungi towards the extract.

\section{Broth dilution}

For broth dilution result, MIC was reported based on the turbidity of cultured cell where the lowest concentration of the extract prevented visible growth of the organism. ${ }^{26} \mathrm{IC}_{50}$ was extrapolated from the graph that was plotted between bacterial growth inhibition percentage versus concentration of sample. $^{12}$

In Table II, both extracts showed inhibitory effect against the $S$. aureus and $B$. subtilis with concentrations ranged from $200 \mu \mathrm{g} / \mathrm{mL}$ to $1500 \mu \mathrm{g} /$ $\mathrm{mL}$. However, the ethanolic extract had a better MIC $(200 \mu \mathrm{g} / \mathrm{mL})$ and $I_{50}(157$ and $175 \pm 1 \mu \mathrm{g} / \mathrm{mL})$ compared to the ethyl acetate extract (700; $650 \pm 0.58 \mu \mathrm{g} / \mathrm{mL}$ and 1500; $1400 \pm 0.6 \mu \mathrm{g} / \mathrm{mL}$ ) against $S$. aureus and $B$. subtilis. Considering that the ethanolic extract was a crude extract, the antibacterial activity was somewhat effective as the MIC and $\mathrm{IC}_{50}$ values of the extract were not far from the positive control with MIC and IC 50 of $100 ; 90 \pm 0.09$ $\mu \mathrm{g} / \mathrm{mL}$ and $70 ; 50 \pm 1.1 \mu \mathrm{g} / \mathrm{mL}$ ) for both $S$. aureus and B. subtilis, respectively.

Table II: Antimicrobial activity of Mallotus paniculatus extract against Staphylococcus aureus and Bacillus subtilis based on the mean inhibitory concentration (MIC) and half maximal inhibitory concentration $\left(\mathrm{IC}_{50}\right)$

\begin{tabular}{|c|c|c|c|c|c|c|}
\hline \multirow{3}{*}{$\begin{array}{l}\text { Test } \\
\text { microorganism }\end{array}$} & \multirow{2}{*}{\multicolumn{2}{|c|}{$\begin{array}{l}\text { Strepto- } \\
\text { mycin } \\
(\mu \mathrm{g} / \mathrm{mL})\end{array}$}} & \multicolumn{4}{|c|}{ Type of extract solvents } \\
\hline & & & \multicolumn{2}{|c|}{$\begin{array}{l}\text { Ethanol } \\
(\mu \mathrm{g} / \mathrm{mL})\end{array}$} & \multicolumn{2}{|c|}{$\begin{array}{l}\text { Ethylacetat } \\
\text { e }(\mu \mathrm{g} / \mathrm{mL})\end{array}$} \\
\hline & MIC & $\mathrm{IC}_{50}$ & MIC & $\mathrm{IC}_{50}$ & MIC & $I C_{50}$ \\
\hline $\begin{array}{l}\text { Staphylococ- } \\
\text { cus aureus }\end{array}$ & 100 & $\begin{array}{l}90 \pm \\
0.09\end{array}$ & 200 & $\begin{array}{l}157 \pm \\
0.58\end{array}$ & 700 & $\begin{array}{l}650 \pm \\
0.58\end{array}$ \\
\hline $\begin{array}{l}\text { Bacillus } \\
\text { subtilis }\end{array}$ & 70 & $\begin{array}{l}50 \pm \\
1.1\end{array}$ & 200 & $\begin{array}{l}175 \pm \\
1\end{array}$ & 1500 & $\begin{array}{l}1400 \\
\pm 0.6\end{array}$ \\
\hline
\end{tabular}

\section{Antioxidant activity}

The results shown in Figures $2 a-2 c$ below represent the half maximal inhibitory concentration $\left(\mathrm{IC}_{50}\right)$ of three different extracts to reduce the absorbance of DPPH by $50 \%$. Low $\mathrm{IC}_{50}$ indicated the extract was more effective in combating oxidative stress. The $\mathrm{IC}_{50}$ of ethanol, ethyl acetate and hexane were recorded as 30,810 and $750 \mu \mathrm{g} / \mathrm{mL}$, respectively (Figures $2 \mathrm{a}$ 2c). Based on these results, the ethanolic extract exhibited the best antioxidant activity. Interestingly, the antioxidant activity of ethanolic extract was comparable with the positive control, ascorbic acid and butylated hydroxytoluene (BHT) that recorded as $19.2 \mu \mathrm{g} / \mathrm{mL}$ and $30 \mu \mathrm{g} / \mathrm{mL}$, respectively. It may be possible that the ethanolic extract contained a lot of antioxidant compounds compared to the ethyl acetate and hexane extracts.

Many studies show that flavonoids and tannins in plants are good antioxidants. M. paniculatus contain 
apigenin, fridelin, quercetin, quercitrin, myricetin, and kaempferol-3-0-l-rhamnosyl which are flavonoid. ${ }^{23}$ Flavonoids consist of phenolic groups that mainly have redox properties which are responsible as reducing agents, hydrogen donors, singlet oxygen quenchers as well as having metallic chelating potential. Flavonoids consist of 15-carbon flavan structure which is arranged in three aromatic rings $\left(C_{6} C_{3} C_{6}\right)$ commonly denoted as $A, B$ and $C$. Several classes of flavonoids give the different level of saturation of the $\mathrm{C}$ ring.

Individual compound within substitution pattern of the $A$ and $B$ rings may affect the phenoxyl radical stability and the antioxidant properties of the substances. ${ }^{27}$ The scavenging activity of natural compounds depends on the location and number of free $-\mathrm{OH}$ groups on the flavonoid skeleton. ${ }^{28}$ Multiple hydroxyl groups on the flavonoids contribute to more effective antioxidants than those with only one. Some previous studies reported that the presence of the ortho-3,4-dihydroxy structure increases the antioxidative activity. ${ }^{29}$

In addition, the interactions of flavonoids with metal ions can contribute to chelate formation. The potential coordination spaces in some structure of flavonoids can chelate many ions of metals and form different complexes. These metal-flavonoid complexes possess stronger free radical scavenging properties than free flavonoids. ${ }^{30}$ They play important role in protection against oxidative stress. This also can be crucial in the prevention of radical generation, which damage target biomolecules.

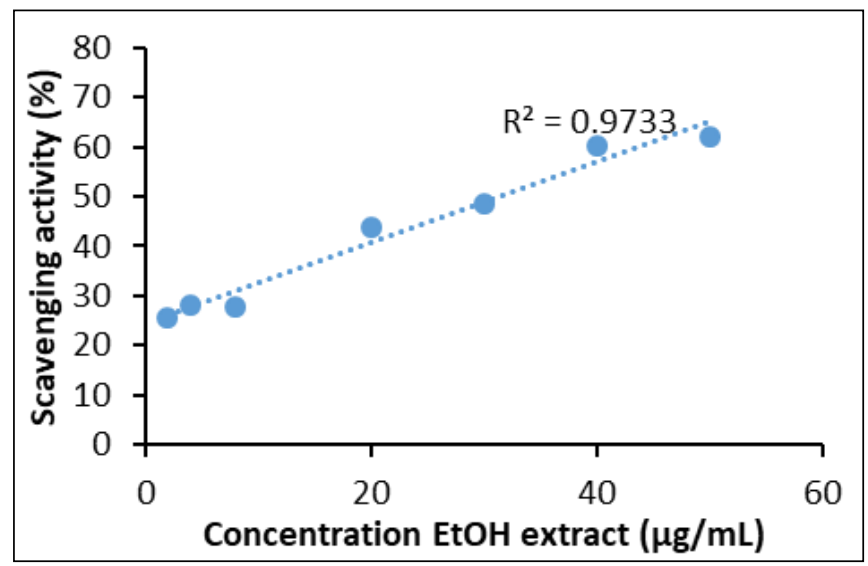

Figure 2a. DPPH scavenging activity of ethanolic Mallotus paniculatus extract

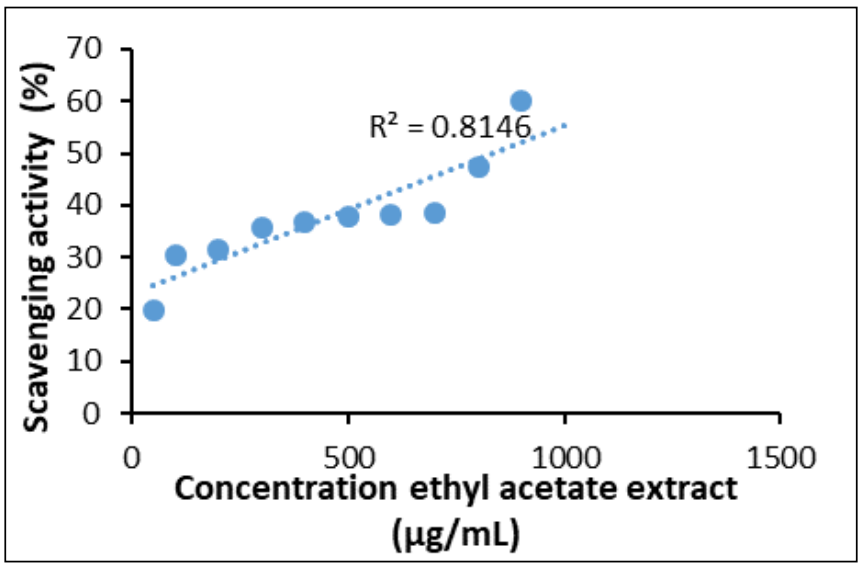

Figure 2b. DPPH scavenging activity of ethyl acetate Mallotus paniculatus extract

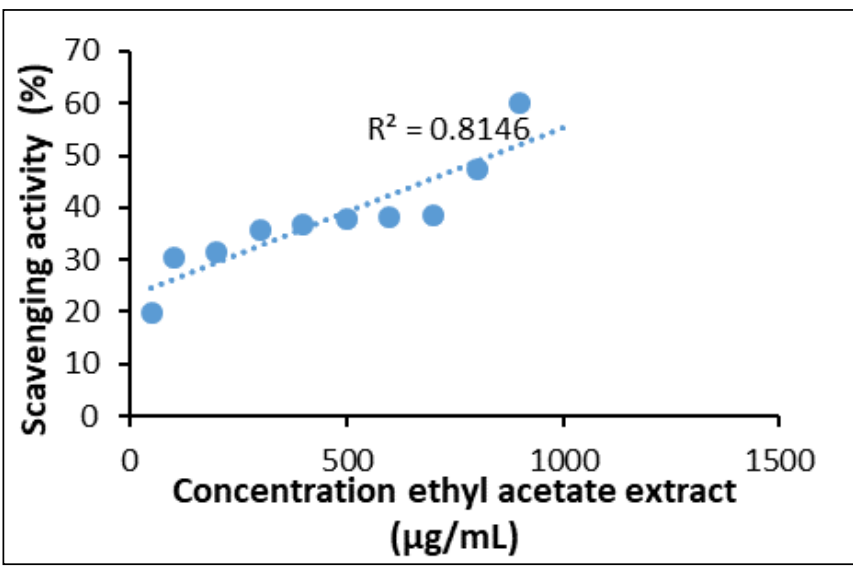

Figure 2c. DPPH scavenging activity of hexane Mallotus paniculatus extract

\section{Cytotoxic activity}

The activity was determined based on the growth inhibition of cancer cells exerted by the extracts. $I_{50}$ values of each extract were estimated based of this inhibition (Table III). The results showed the ethanolic extract demonstrated the most cytotoxic effect against McF-7 $(230 \pm 3.1 \mu \mathrm{g} / \mathrm{mL})$ and HeLa (280 $\pm 1.2 \mu \mathrm{g} / \mathrm{mL}$ ) compared to the ethyl acetate and hexane extracts $(700 \pm .2 .5 \mu \mathrm{g} / \mathrm{mL} ; 1100 \pm 2.32 \mu \mathrm{g} /$ $\mathrm{mL}$ and $400 \pm 1.5 \mu \mathrm{g} / \mathrm{mL} ; 700 \pm 3.4 \mu \mathrm{g} / \mathrm{mL}$, respectively). Meanwhile, the ethyl acetate extract $(250 \pm 0.9)$ showed the most significant effect against HT-29 compared to the other two extracts (300 $\pm 1.94 \mu \mathrm{g} / \mathrm{mL}$ and $1500 \pm 2.23 \mu \mathrm{g} / \mathrm{mL}$ ). When all of these extract were tested on normal cells, Vero cells; they all showed very little effect.

The cytotoxic effect demonstrated by M. paniculatus in this study is possibly explained by the presence of flavonoids and other bioactive compounds in the plant. ${ }^{23}$ Flavonoids were also claimed to have antioproliferative and apoptosisapromoting effects 
Table III: Anticancer activity of Mallotus paniculatus leave extract against various cancer cells based on $I_{50}$ values

\begin{tabular}{llrl}
\hline \multirow{2}{*}{ Cell lines } & \multicolumn{3}{l}{$\mathrm{I} \mathrm{C}_{50}(\boldsymbol{\mu g} / \mathrm{mL})^{*}$} \\
\cline { 2 - 4 } & \multicolumn{3}{l}{ Types of extract solvents } \\
\cline { 2 - 4 } & \multicolumn{1}{l}{ Ethanol } & \multicolumn{1}{l}{ Ethyl acetate } & Hexane \\
\hline Breast cancer (McF-7) & $230 \pm 3.1$ & $700 \pm 2.5$ & $400 \pm 1.5$ \\
Colon cancer (HT-29) & $1500 \pm 2.23$ & $250 \pm 0.9$ & $300 \pm 1.94$ \\
Cervical cancer (HeLa) & $280 \pm 1.2$ & $1100 \pm 2.32$ & $700 \pm 3.4$ \\
Kidney epithelial normal cell (Vero) & $>1000 \pm 1.5$ & $>1000 \pm 3.5$ & $>1000 \pm 0.8$ \\
\hline
\end{tabular}

${ }^{*}$ Low $I C_{50}$ value indicated the extract was more potent in inhibiting the growth of cancer cells

against cancer cells apart from the antibacterial and antioxidant activities mentioned above. ${ }^{31}$

They also have the ability to block cell cycle followed by apoptosis. ${ }^{32}$ They have recently been used for the treatment of prostate, pancreatic, breast, cervical, and ovarian cancers. ${ }^{33}$ From previous studies, flavonoids have been shown to induce cell cycle arrest in $\mathrm{G} 2$ and mobile phase of cell cycle, inhibited heat-shock protein, tyrosine kinase and Ras protein as well as downregulated oestrogen receptor-binding capacity. ${ }^{34}$ As most pathogenesis of cancer involve genetic abnormalities that result in p53-mutated proteins, downregulation of these proteins by flavonoid intake also affect cancer growth. ${ }^{34}$

Interestingly, other Mallotus species such as M. apelta was found to have a strong cytotoxic effect against cancer cells. Benzopyran, 6-[10-oxo-30(R)-hydroxybutyl]-5,7-dimethoxy-2,2-dimethyl-2H-1-benzopyran, that was present in the plant was cytotoxic against two human cancer cell lines, human hepatocellular carcinoma and rhabdosarcoma. ${ }^{35}$ While another benzopyrans, Malloapelta B detected in the same plant, was shown to be cytotoxic against three cancer cell lines KB (human epidermoid carcinoma), FL (fibrillary sarcoma of the uterus), and Hep-2 (human hepatocellular carcinoma) cells. ${ }^{35}$

\section{CONCLUSION}

The current study reveals that $M$. paniculatus extracts possess several potential medicinal activities. Based on the antibacterial results, the ethanolic and ethyl acetate extracts show inhibitory effect against the gram positive bacteria. Meanwhile, for antioxidant property, the ethanolic extract exhibits strong free radical scavenging activity, comparable with the positive control. Interestingly, the ethanol and ethyl acetate extracts record a promising cytotoxic activity against three cancer cell lines; MCF-7, HeLa, and HT-29. These indicate that this plant contains significant compounds with potential medicinal properties.

\section{CONFLICT OF INTEREST}

Nothing to declare

\section{ACKNOWLEDGEMENT}

Not applicable

\section{REFERENCES}

1. Lahlou M. The Success of Natural Products in Drug Discovery. Pharmacology \& Pharmacy, 2013, 4, 17-31

2. Department of Agriculture (USDA). Retrieved from http://editors.eol.org/eoearth/wiki/ Department_of_Agriculture (USDA). 2011.

3. Veeresham C. Natural Products Derived from Plants as A Source of Drugs. J Adv Pharm Technol Res. 2012 Oct-Dec;3(4): 200-201.

4. Newman DJ and Cragg GM. Natural Products as Sources of New Drugs Over the 30 Years from 1981 to 2010. J Nat Prod. 2012 Mar 23;75 (3):311-35.

5. Ji HF, Li XJ, Zhang HY. Natural products and drug discovery. Can thousands of years of ancient medical knowledge lead us to new and powerful drug combinations in the fight against cancer and dementia? EMBO Rep., 2009; 10(3): 194-200.

6. Jamshidi-Kia F, Lorigooini Z, Amini-Khoei H. Medicinal plants: Past history and future perspective. J Herbmed Pharmacol. 2018; 7 (1): 1-7.

7. Firenzuoli F, Gori L. Herbal medicine today: clinical and research issues. Evid Based Complement Alternat Med. 2007;4(Suppl 1):37-40.

8. Yuan $\mathrm{H}, \mathrm{Ma} \mathrm{Q}, \mathrm{Ye} \mathrm{L}$ and Piao G. Review article: The Traditional Medicine and Modern 
Medicine from Natural Products. Molecules 2016, 21, 559

9. Alsarhan A, Sultana N, Al-Khatib A, Abdul Kadir MR. Review on Some Malaysian Traditional Medicinal Plants with Therapeutic Properties. Journal of Basic \& Applied Sciences; 2014, 10; 149-159

10. Bachok MF, Mohd Yusof BN, Ismail A, Abdul Hamid, A. Review Article: Effectiveness of traditional Malaysian vegetables (ulam) in modulating blood glucose levels. Asia Pac J Clin Nutr; 2014, 23(3):369-376 369

11. Aruoma OI, Colognato, R, Fontana, I, Gartlon J, Migliore L, Koike, K. Molecular effects of fermented papaya preparation on oxidative damage, MAP Kinase activation and modulation of the benzo pyrene mediated genotoxicity. Biofactors, 2006; 26(2): 147-59.

12. Yusof SF. 2013. Ensiklopedia Tumbuhan Ubatan Malaysia. Ar-risalah Product Sdn. Bhd.139140.ISBN967-0268-82-6

13. Sierra SEC, Van Welzen PC. A Taxonomic Revision of Mallotus Section Mallotus (Euphorbiaceae) In Malesia. BLUMEA, 2005. 50: 249 -274.

14. Rivière C, Heyden YV, Thanh NK, Quetin-Leclercq J. Mallotus species from Vietnamese mountainous areas: Phytochemistry and pharmacological activities. Article in Phytochemistry Reviews, 2010.

15. Setzer MC, Werka JS, Irvine AK, Jackes BR, Setzer WN. Biological activity of rainforest plant extracts from far north Queensland, Australia. In Biologically Active Natural Products for the 21st Century, Williams, L.A.D. Ed.; Research Signpost: Trivandrum, India, 2006 pp. 21-46.

16. Nguyen Hoai N, Dejaegher B, Tistaert C. Development of HPLC fingerprints for Mallotus species extracts and evaluation of the peaks responsible for their antioxidant activity. J Pharm Biomed Anal, 2009. 50:753-763

17. Irshad M, Aziz S, Rehman $\mathrm{H}$, et al. Antioxidant and antimicrobial activities of essential oil of Skimmea laureola growing wild in the State of Jammu and Kashmir. Journal of Medicinal Plants Research, 2012; 6(9), 1680-1684.

18. Chew KK, Khoo MZ, Ng SY, Thoo YY, Aida Wan WM. Effect of ethanol concentration, extraction time and extraction temperature on the recovery of phenolic compounds and antioxidant capacity of Orthosiphon stamineus extracts. International Food Research Journal. Vol. 18, Iss. 4, (2011): 1427-1435
19. Veeru P, Kishor MP, Meenakshi M. Screening of medicinal plant extracts for antioxidant activity. Journal of Medicinal Plants Research, 2009; 3(8), 608-612.

20. Shridhar CG, Sridevi IP, Vijay MK, et al. In vitro antioxidant and anticancer activity of Leea indica leaf extracts on human prostate cancer cell lines. Integr Med Res., 2017; 6(1): 79-87.

21. Malanovic N, Lohner K. Gram-positive bacterial cell envelopes: The impact on the activity of antimicrobial peptides. Biochimica et Biophysica Acta, 2016; 1858, 936-946

22. Pinelo M, Manzocco MJ, Nunez MJ, Nicoli MC. Solvent effect on quercetin antioxidant capacity. Food Chemistry, 2004; 88, 201-207

23. Tistaerta C, Chataignéb G, Dejaeghera B, Rivièreb C, Nguyen N, Chau VHM, QuetinLeclercq J, Vander HY. Multivariate data analysis to evaluate the fingerprint peaks responsible for the cytotoxic activity of Mallotus species. Journal of Chromatography B, 2012; 910, 103- 113

24. Mishra MP, Rath S, Swain SS, Ghosh G, Das D, Padhy RN. In vitro antibacterial activity of crude extracts of 9 selected medicinal plants against UTI causing MDR bacteria. Journal of King Saud University. Volume 29, Issue 1, January 2017, 84-95

25. Brahmachari G, Mandal NC, Roy R, et al. A new pentacyclic triterpene with potent antibacterial activity from Limnophila indica Linn. (Druce). Fitoterapia, 2013; 90; 104-111

26. Wang J, Liu H, Zhao J, Gao H, Zhao L, Liu Z, Chen Y, Sui P. Antimicrobial and Antioxidant Activities of the Root Bark Essential Oil of Periploca sepium and Its Main Component 2Hydroxy-4-methoxybenzaldehyde. Molecules, 2010; 15, 5807-5817

27. Wojdyło A, Oszmiański J, Czemerys R. Antioxidant activity and phenolic compounds in 32 selected herbs. Food Chemistry, 2007; 105 (3), 940-949

28. Lupea AX, Pop M, Cacig S. Structure-Radical Scavenging Activity Relationships of Flavonoids from Ziziphus and Hydrangea Extracts. Revista de Chimie -Bucharest. 2008. 67(18):2058-70.

29. Geldof N, Engeseth NJ. Antioxidant capacity of honeys from various floral sources based on the determination of oxygen radical absorbance capacity and inhibition of the in vitro lipoprotein oxidation in human serum samples. J. Agric. Food. Chem., 2002; 50, 3050-3055. 
30. Symonowicz M, Kolanek M. Flavonoids and their Properties to form Chelate Complexes.

Biotechnol Food Sci, 2012; 76 (1), 35-41

31. Skrovankova S, Sumczynski D, Mlcek J, Jurikova $\mathrm{T}$, Sochor J. Bioactive compounds and antioxidant activity in different types of berries. Int. J. Mol. Sci., 2015; 16, 24673-24706

32. Singh RP, Agarwal R. Natural flavonoids targeting deregulated cell cycle progression in cancer cells. Current Drug Targets, 2006; 7, 345354

33. Brusselmans K, Vrolix R, Verhoeven G, Swinnen JV. Induction of cancer cell apoptosis by flavonoids is associated with their ability to inhibit fatty acid synthase activity. Journal of Biological Chemistry, 2005; 280, 5636-5645

34. Veeramuthu D, Tharsius Raja WR, Al-Dhabi NA, Savarimuthu I. Flavonoids: Anticancer Properties. 2017, 288-303.

35. Van Chau M, Le MH, Phan VK. Chemical investigations and biological studies of Mallotus apelta. VI. Cytotoxic constituents from Mallotus apelta. Tap Chi Hoa Hoc, 2005; 43, 5-6 